\title{
Factors associated with the presence of diabetic ketoacidosis at diagnosis of diabetes in children and young adults: a systematic review
}

\author{
Juliet A Usher-Smith academic clinical fellow ${ }^{1}$, Matthew J Thompson senior clinical scientist ${ }^{2}$, \\ Stephen J Sharp senior statistician ${ }^{3}$, Fiona M Walter clinical lecturer in general practice ${ }^{1}$ \\ ${ }^{1}$ General Practice and Primary Care Research Unit, University of Cambridge, Cambridge CB2 0SR, UK; ${ }^{2}$ Department of Primary Health Care, \\ University of Oxford, Oxford OX3 7LF, UK; ${ }^{3} \mathrm{MRC}$ Epidemiology Unit, Institute of Metabolic Science, Cambridge CB2 0QQ
}

\begin{abstract}
Objective To identify the factors associated with diabetic ketoacidosis at diagnosis of type 1 diabetes in children and young adults.

Design Systematic review.

Data sources PubMed, EMBASE, Web of Science, Scopus, and Cinahl and article reference lists.

Study selection Cohort studies including unselected groups of children and young adults presenting with new onset type 1 diabetes that distinguished between those who presented in diabetic ketoacidosis and those who did not and included a measurement of either $\mathrm{pH}$ or bicarbonate in the definition of diabetic ketoacidosis. There were no restrictions on language of publication.

Results 46 studies involving more than 24000 children in 31 countries were included. Together they compared 23 different factors. Factors associated with increased risk were younger age (for $<2$ years old $v$ older, odds ratio 3.41 (95\% confidence interval 2.54 to 4.59 ), for $<5$ years $v$ older, odds ratio 1.59 (1.38 to 1.84)), diagnostic error (odds ratio 3.35 (2.35 to 4.79)), ethnic minority, lack of health insurance in the US (odds ratio 3.20 (2.03 to 5.04$)$ ), lower body mass index, preceding infection (odds ratio 3.14 (0.94 to 10.47)), and delayed treatment (odds ratio 1.74 (1.10 to 2.77)). Protective factors were having a first degree relative with type 1 diabetes at the time of diagnosis (odds ratio 0.33 (0.08 to 1.26)), higher parental education (odds ratios 0.4 (0.20 to 0.79$)$ and 0.64 (0.43 to 0.94 ) in two studies), and higher background incidence of type 1 diabetes (correlation coefficient -0.715 ). The mean duration of symptoms was similar between children presenting with or without diabetic ketoacidosis ( 16.5 days (standard error 6.2) and 17.1 days (6.0) respectively), and up to $38.8 \%$ (285/735) of children who presented with diabetic ketoacidosis had been seen at least once by a doctor before diagnosis.
\end{abstract}

Conclusions Multiple factors affect the risk of developing diabetic ketoacidosis at the onset of type 1 diabetes in children and young adults, and there is potential time, scope, and opportunity to intervene between symptom onset and development of diabetic ketoacidosis for both parents and clinicians.

\section{Introduction}

Type 1 diabetes is one of the most common endocrine diseases in children. Worldwide, an estimated 65000 children under 15 years old develop the disease each year, and the global incidence in children continues to increase at a rate of $3 \%$ a year. ${ }^{12}$ The current incidence in the UK is around 26/100 000 per year. ${ }^{3}$

Between $10 \%$ and $70 \%$ of these diagnosed children present in diabetic ketoacidosis, a metabolic derangement characterised by the triad of hyperglycaemia, acidosis, and ketonuria. The current criteria for diagnosis published by the International Society for Paediatric and Adolescent Diabetes is blood glucose $>11 \mathrm{mmol} / \mathrm{L}$, venous $\mathrm{pH}<7.3$ or bicarbonate $<15 \mathrm{mmol} / \mathrm{L}$, and ketonaemia and ketonuria. ${ }^{4}$ It carries a substantial risk of life threatening complications such as cerebral oedema and is the commonest cause of diabetes related death in children. ${ }^{5}$ The longer term clinical course of type 1 diabetes also seems to be influenced by it: children with diabetic ketoacidosis at diagnosis have poorer glycaemic control, ${ }^{6}$ less residual $\beta$ cell function up to two years after diagnosis, ${ }^{7}$ and a lower frequency of remission. ${ }^{89}$

It is unclear why some children present in diabetic ketoacidosis whereas others do not and whether the development of diabetic ketoacidosis is a consequence of delayed diagnosis and treatment or whether it reflects a particularly aggressive form of diabetes. ${ }^{10}$ Understanding which factors are associated with diabetic ketoacidosis at diagnosis and the relative importance of delayed diagnosis and treatment is, therefore, important. This potentially informs both our understanding of the disease as well as the development of patient, professional, and population based interventions to reduce the proportion of children presenting in diabetic ketoacidosis. Several individual factors from individual 
studies have been quoted in guidelines and consensus statements. ${ }^{11-13}$ To our knowledge, this is the first systematic review of all factors associated with diabetic ketoacidosis at the diagnosis of type 1 diabetes in children and young adults.

\section{Methods}

\section{Search strategy}

An electronic literature search of PubMed, EMBASE, Web of Science, Scopus, and Cinahl up to March 2011 was performed using a combination of subject headings and free text incorporating "diabetic ketoacidosis", "diabetes and ketoacidosis", and "diagnosis" limited to infants, children, or adolescents (see appendix on bmj.com for complete search strategy). The search was then extended by manually screening the reference lists of all included papers.

\section{Study selection}

Included studies fulfilled all of the following criteria: published as a primary research paper in a peer reviewed journal; included cohorts of children and young adults presenting with new onset (that is, previously undiagnosed) type 1 diabetes who had not been selected based on other characteristics; distinguished between those children who presented in diabetic ketoacidosis and those who did not; and included a measurement of either $\mathrm{pH}$ or bicarbonate in the definition of diabetic ketoacidosis. Studies including only highly selected groups-such as neonates or children being treated with high dose corticosteroids or receiving chemotherapy-as well as drug trials and conference proceedings were excluded. We chose to include all studies which defined diabetic ketoacidosis based on measurement of either $\mathrm{pH}$ or bicarbonate as this was an exploratory review not limited by time or language of publication, and we expected a range of different definitions.

One reviewer (JAUS) performed the search and screened the titles and abstracts to exclude papers that were clearly not relevant. A second reviewer (FMW) independently assessed a random selection of papers excluded at that stage. For papers where a definite decision to reject could not be made based on title and abstract alone, the full text was examined. At least two reviewers (JAUS and FMW or MJT) independently assessed all full text papers, and those not meeting the inclusion criteria by both researchers were excluded. Papers in which it was unclear whether the inclusion criteria were met were assessed by a third researcher (MJT or FMW), and where either the definition of diabetic ketoacidosis was not given or we were unable to interpret the data presented adequately we contacted the authors for clarification.

\section{Quality assessment}

Quality assessment was conducted independently by at least two reviewers (JAUS and FMW or MJT). We used the Critical Appraisal Skills Programme guidelines for case control and cohort studies ${ }^{14}$ as an initial framework and classified each as key paper, satisfactory, unsure, fatally flawed, or irrelevant as in the approach of Dixon-Woods et al. ${ }^{15}$ We excluded papers classified as fatally flawed or irrelevant and discussed those classified as unsure at consensus meetings.

\section{Data extraction and synthesis}

Characteristics of included studies were extracted; these included period of study, number and type of study centres, study design, methods of recruitment, sample size, age and number of participants, and definition of diabetic ketoacidosis. Using a standardised form to minimise bias, at least two researchers (JAUS and FMW or MJT) independently extracted data on all factors for which there were data available for children presenting both with and without diabetic ketoacidosis. The factors were grouped into individual, family, physician, disease related, and others. Studies reported the effects of risk factors in a variety of ways, and hence various approaches to synthesis were needed. We expressed the effect of a risk factor as an odds ratio with $95 \%$ confidence interval where possible, but where the data did not allow this we compared the mean and standard deviation of the risk factor between those individuals with and without diabetic ketoacidosis and expressed this as mean and standard error. When studies recruited children over more than one time period and it was possible to separate all the data into different time periods, we used only the most recent period. In all other cases we combined the data from all time periods.

\section{Statistical methods}

Where possible, we combined odds ratios using random effects meta-analysis: data were analysed with Stata (version 11.1), and we assessed heterogeneity between studies using Cochran's Q test and the $\mathrm{I}^{2}$ statistic. ${ }^{16}{ }^{17}$ Where the mean and standard deviation of the risk factor were compared between those individuals with and without diabetic ketoacidosis, we used a two sample $t$ test. Significance was set at $\mathrm{P}<0.05$, and $95 \%$ confidence intervals are quoted throughout.

\section{Results}

After duplicates were removed, the search identified 1441 papers. One author (JAUS) excluded 1333 of these as clearly irrelevant on the basis of title and abstract. A second author (FMW) independently reviewed a random selection of these and was in complete agreement. A further 71 papers were excluded after full text assessment by at least two authors (JAUS and FMW or MJT). The most common reasons for exclusion were that the papers included only a measure of the frequency of diabetic ketoacidosis and no further clinical details or it was not possible to separate the data for children with new onset diabetes (fig 1). We excluded three papers after contacting the authors as it was not possible to establish the definition of diabetic ketoacidosis used. A further eight papers were identified through citation searching. One paper compared the severity of type 1 diabetes at presentation in south east Sweden and Lithuania and so is reported as two studies. ${ }^{18}$ The analysis is therefore based on 46 studies.

\section{Study characteristics}

The 46 eligible studies included more than 24000 children in 31 different countries. Included studies showed considerable heterogeneity in terms of size, setting, length of study, and the proportion of children presenting in diabetic ketoacidosis (tables 1 and 2). Nearly three quarters of children $(70 \%)$ were recruited from Canada $(n=3947)$, Austria $(n=3471)$, Finland $(n=3002)$, Germany ( $\mathrm{n}=2533)$, Sweden $(\mathrm{n}=2304)$, and the US $(\mathrm{n}=2181)$. Most studies included children from birth to 18 years old, but two included young adults up to the ages of 20 and 21 years. ${ }^{19} 20$ Studies used a wide range of definitions of diabetic ketoacidosis, but all included either $\mathrm{pH}$ values of $\leq 7.2$ to $<7.36$ or bicarbonate values of $<15$ to $\leq 21 \mathrm{mmol} / \mathrm{L}$. One study, which used two different definitions of diabetic ketoacidosis on the same cohort of children ( $\mathrm{pH}<7.3$ alone or combined with bicarbonate $<15$ $\mathrm{mmol} / \mathrm{L}),{ }^{21}$ found an increased frequency of diabetic ketoacidosis when the definition based on $\mathrm{pH}$ alone was used $(22.4 \%$ 
compared with $18.1 \%$ ) but found no differences in the other conclusions based on definition used.

\section{Study quality}

All included studies were cohort studies and most recruited children retrospectively from hospital or clinic records. Study quality was variable, and formal assessment of ascertainment was performed in only 16 studies. We classified 12 studies as key papers (identified in table 1) and 28 as satisfactory. Only one study was excluded based on quality alone (see fig 1) as we were unable to adequately interpret the numerical data after contacting the author.

\section{Analysis of identified factors}

Together, the 46 studies compared 23 factors in children presenting with and without diabetic ketoacidosis. Table 3 shows these factors along with the number of studies and children included for each, and fig 2summarises the effect of these factors on the risk of presenting with diabetic ketoacidosis.

\section{Individual factors}

\section{Age}

Age was the most common factor described: 32 studies reported the effect of age on presentation, and 24 included data on the frequency of diabetic ketoacidosis in children grouped into different age ranges (fig 3). ${ }^{8}{ }^{19-41}$ Together, they showed that children $<2$ years old had three times the risk of presenting in diabetic ketoacidosis as children aged $\geq 2$ years (odds ratio 3.41 (95\% confidence interval 2.54 to 4.59 ), $\mathrm{P}<0.001, \mathrm{I}^{2}=21.1 \%$ ), and this association continued up to age 5 (odds ratio 1.59 (1.38 to 1.84$), \mathrm{P}<0.001, \mathrm{I}^{2}=23.5 \%$ ).

Four studies reported instead the mean age at diagnosis. ${ }^{37} 384243$ Combining these showed that children who presented with diabetic ketoacidosis tended to be younger than those without, but the difference was negligible (8.6 (SE 4.0) years $v 8.7$ (3.5) years, $\mathrm{P}=0.007)$. Data from the remaining six studies were insufficient for meta-analysis; four showed that younger children were more likely to present in diabetic ketoacidosis ${ }^{44-47}$ while two reported no difference in mean $^{48}$ or median ${ }^{49}$ age at diagnosis.

\section{Sex}

Twenty one studies reported the effect of sex on the frequency of diabetic ketoacidosis, of which 20 showed no effect and one $(n=2121)$ reported a small but statistically significant increase in the frequency in girls (odds ratio 1.30 (1.07 to 1.58),

$\mathrm{P}=0.0079) .{ }^{25}$ Twelve studies compared the proportion of each gender presenting with and without diabetic ketoacidosis, and together gave a pooled odds ratio for boys of 0.93 (0.76 to 1.14 , $\left.\mathrm{P}=0.472, \mathrm{I}^{2}=51.8 \%\right){ }^{18}$ (fig 4). ${ }^{2125} 2635364050-53$ Of the remaining nine studies, eight lacked sufficient data for

meta-analysis $202414246-4854$ and one was a multivariate analysis of 262 children - which showed that, although female sex was significantly associated with increased risk of delayed diagnosis (symptomatic period $\geq 4$ weeks) (odds ratio 2.78 (1.09 to 7.14), $\mathrm{P}=0.033$ ), it was not associated with an increased risk of severe diabetic ketoacidosis (odds ratio 0.68 (0.26 to 1.83 ), $\mathrm{P}=0.450) .{ }^{27}$

\section{Ethnicity}

Seven studies explored the effects of ethnicity. Because of the heterogeneity of the populations, it was not possible to establish whether the frequency of diabetic ketoacidosis was significantly different in any particular race or ethnic group. However, five studies compared the frequency of diabetic ketoacidosis between two different ethnic groups. All showed a significant difference in the frequency of diabetic ketoacidosis, and in each case the ethnic minority group experienced an increased risk of diabetic ketoacidosis - in the US, non-Hispanic white people $v$ others (odds ratio 0.55 (0.32 to 0.96)), ${ }^{36}$ white people $v$ Hispanic (odds ratio 0.33 (0.14 to 0.76$)),{ }^{55}$ and non-Hispanic white $v$ Hispanic (odds ratio $0.58(0.37$ to 0.89$))^{56}$; and in the UK, white $v$ others (odds ratio $0.39(0.15$ to 0.98$))^{57}$ and non-Asian $v$ Asian (odds ratio 0.35 (0.18 to 0.66$)){ }^{22} \mathrm{~A}$ French study also reported that parental birth in France had no significant effect on the frequency of diabetic ketoacidosis, ${ }^{43}$ and a Kuwaiti study showed no difference between Kuwaiti nationals, Arabs, Asians, and those with no identified citizenship. ${ }^{47}$

\section{Family history of diabetes}

Six studies reported the effect of family history of diabetes on presentation with diabetic ketoacidosis, of which five examined the influence of having a relative with diabetes at the time of diagnosis. Although having a first degree relative with type 1 diabetes decreased the frequency of diabetic ketoacidosis in three studies (odds ratios $0.60(0.44 \text { to } 0.82)^{58}$ and 0.15 (0.05 to $0.41)^{47}$ (not combined as $\mathrm{I}^{2}=84.7 \%$ ) and $\mathrm{P}<0.01^{20}$ ), it did not predict a diagnosis of new onset diabetes before progression to diabetic ketoacidosis in a US study after adjustment for age, sex, whether children were diagnosed in primary or secondary care, and duration of symptoms. ${ }^{44} \mathrm{~A}$ German study which adjusted for age, sex, having a single parent, and social status also failed to show a significant association with a family history of either type 1 or type 2 diabetes in siblings, parents, or grandparents (odds ratio for positive family history $v$ no family history 0.58 (0.20 to 1.66$), \mathrm{P}=0.312){ }^{27}$

Two studies examined the effect of being the first or second affected member of a family, thereby separating the effect of having an increased genetic risk of developing diabetes from the environmental effects of having a family member with diabetes at the time of diagnosis. Among Finnish children followed for a median of 7.7 years after initial diagnosis, those with a first degree relative with diabetes at the time of diagnosis had a significantly lower frequency of diabetic ketoacidosis than those in whom a family member was subsequently diagnosed with diabetes during the follow-up period (4.9\% (4/90) v $21.4 \%$ (7/30), $\mathrm{P}<0.05$; odds ratio 0.16 (0.04 to 0.59$)$ ). However, there was no difference between children in whom a family member was subsequently diagnosed with diabetes during the follow-up period and those without a family history at the end of the follow-up period (odds ratio 0.93 (0.39 to 2.20)). ${ }^{58}$ A small UK study also showed that children who were the second affected child in a family were less likely to present in diabetic ketoacidosis than first affected children (odds ratio for second $v$ first affected 0.07 (0.003 to 1.51$), \mathrm{n}=79){ }^{48}$

\section{Body mass index}

Two studies reported on the association between body mass index and a diagnosis of diabetic ketoacidosis and both showed a higher frequency of diabetic ketoacidosis in those children with a lower body mass index. ${ }^{41} 53$

\section{Parental consanguinity}

Two small studies from Saudi Arabia with parental consanguinity rates of $>40 \%$ ( $19 / 40$ and $47 / 110)$ failed to show a significant difference in the rate of diabetic ketoacidosis in children of consanguineous parents (combined odds ratio 1.19 (0.59 to 2.37$\left.), \mathrm{P}=0.63, \mathrm{I}^{2}=0\right){ }^{28}{ }^{29}$ 


\section{Family factors \\ Parental education}

Three studies reported on the influence of parental education. Having a mother with higher than secondary education was protective against developing diabetic ketoacidosis in Lithuania (odds ratio 0.4 (0.20 to 0.79$)$ ), ${ }^{18}$ and in Finland children from families in which at least one parent had an academic degree had a lower incidence of diabetic ketoacidosis at presentation than those without $(16.9 \%$ (43/254) v 24.4\% (105/431), $\mathrm{P}<0.05$, odds ratio 0.64 ( 0.43 to 0.94$)) .{ }^{34}$ The third study, set in Germany, did not report the effect of parental education on the presence or absence of diabetic ketoacidosis at presentation, but multivariate analysis showed that children from families in which parents had $\leq 9$ years of education had a significantly increased risk of severe diabetic ketoacidosis $(\mathrm{pH} \leq 7.2)$ (odds ratio 3.54 (1.10 to 11.35$), \mathrm{P}$ for trend $=0.034$ ) compared with children whose parents had $\geq 12$ years of education, even after adjustment for rates of delayed diagnosis. ${ }^{27}$

\section{Family structure}

Three studies explored the effects of family structure and found that neither living in a single parent family ${ }^{48}$ nor the number of children in the family ${ }^{43}$ were significantly associated with diabetic ketoacidosis at diagnosis (odds ratio 1.85 (0.43 to 7.82), $\left.\mathrm{P}=0.411^{27}\right)$.

\section{Health insurance status}

Three studies examined the influence of insurance status. Two US studies reported that lack of private insurance was a risk factor for presenting in diabetic ketoacidosis, with significantly more patients with either Medicaid or no insurance presenting in diabetic ketoacidosis (62\% (13/21) and 48\% (40/83) compared with $34 \%$ (40/118) and $22.5 \%$ (62/276) respectively, combined odds ratio 3.20 (2.03 to 5.04), $\left.\mathrm{P}<0.001, \mathrm{I}^{2}=0\right) .{ }^{36}{ }^{37}$ Children with no insurance also had a greater risk of presenting in diabetic ketoacidosis compared with those receiving Medicaid (odds ratio 2.84 (1.16 to 6.93)), but there was no difference between those with private insurance and those receiving Medicaid (odds ratio 0.54 ( 0.26 to 1.10$)) .{ }^{36}$ In contrast, a French study showed that the presence or absence of free medical assistance (aide medicale gratuite) was not significantly associated with diabetic ketoacidosis at diagnosis of diabetes. ${ }^{43}$

\section{Rural or urban residence}

Three studies found that living in rural or urban areas had no significant effect on rates of diabetic ketoacidosis at diagnosis. In Finland there was no difference in frequency of diabetic ketoacidosis between families living in a city, town, or suburb compared with those living in a village or rural areas, ${ }^{34}$ while in Sweden and Lithuania the rates of diabetic ketoacidosis were not significantly different in those living in cities or small towns compared with those in villages (odds ratios 2.06 ( 0.80 to 5.30) and 0.63 (0.32 to 1.27 ) respectively). ${ }^{18}$

\section{Family income, parental employment, and social status}

Three studies examined the effect of family income. Two European studies found that family income had no significant effect on risk of presenting in diabetic ketoacidosis. ${ }^{34} 43$ In contrast, a Canadian study, which adjusted for age and sex, showed that being from a family in the two lowest quintiles of family income was associated with an increased risk of diabetic ketoacidosis (odds ratio 1.38 (1.17 to 1.63$)$ ). ${ }^{46}$
Two studies examined the effect of parental employment on the frequency of diabetic ketoacidosis: in Sweden having a mother who did not work significantly increased the risk of presenting in diabetic ketoacidosis (odds ratio 4.8 (1.8 to 13.1)), whilst in Lithuania the father's employment status had no effect on the rate of diabetic ketoacidosis (odds ratio 1.17 (0.53 to 2.57$)$ ). ${ }^{18}$ Only one study from the UK assessed the influence of social status. It did not provide numerical data, but reported that children with parents in social classes 3-5 were more likely to present in diabetic ketoacidosis than those in social classes 1 and $2(\mathrm{P}<0.05){ }^{20}$

\section{Physician factors Delayed diagnosis}

Four studies explored the impact of delayed diagnosis (delay $>24$ hours for any reason) on the development of diabetic ketoacidosis. All reported that a significant proportion (16-51\%) of children experienced a delay, but it was not possible to combine data because of different definitions of end points used. Delay of more than 24 hours between initial presentation to a primary or secondary care provider and referral to a multidisciplinary diabetes team in the UK was associated with an increased risk of presenting with diabetic ketoacidosis $(52.3 \%$ $v 20.5 \%, \mathrm{P}<0.05$, odds ratio 4.26 (1.54 to 11.79$)) .{ }^{57} \mathrm{~A}$ similar increase in risk occurred in children who were not diagnosed on the day of admission to a US children's hospital (59\% (17/29) v $33 \%(35 / 105), \mathrm{P}=0.0178$, odds ratio $2.83(1.22$ to 6.58$)) .{ }^{37} \mathrm{In}$ contrast, two European studies found no effect when there was a delay between the first medical consultation and hospitalisation (odds ratio 0.79 ( 0.31 to 2.00$))^{43}$ or delay of more than 24 hours between the first visit and diagnosis (odds ratio 0.98 (0.73 to $1.31))^{42}$

\section{Diagnostic error}

Four studies in the US, France, and Poland looked specifically at the outcome of children in whom the diagnosis of type 1 diabetes was not made at the first medical consultation because of diagnostic error, judged to have occurred when children were not diagnosed on their first visit, either because they were given a misdiagnosis or signs and symptoms were missed or not recognised. Such children had a threefold increased risk of presenting in diabetic ketoacidosis (combined odds ratio 3.35 ( 2.35 to 4.79 ), $\mathrm{P}<0.001, \mathrm{I}^{2}=0 \%$ ) (fig 5)..$^{37} 435960$ This risk was independent of the presence or absence of infection preceding diagnosis, ${ }^{59}$ but diagnostic error was significantly more likely to occur in younger children: the mean age of children who presented with diabetic ketoacidosis was 5.4 (standard error 4.4) years when the diagnosis was missed compared with 8.8 (4.0) years when the diagnosis was not missed $(\mathrm{P}<0.001) .{ }^{37}$

\section{Number of medical consultations before diagnosis}

Two studies reported the number of medical consultations that occurred before the diagnosis of diabetes. A Canadian study found that $84 \%(207 / 247)$ of children had been seen in primary care before referral to secondary care: $66 \%(163 / 247)$ on the day of diagnosis, $14 \%$ (35/247) once, and 4\% (10/247) at least twice before the date of diagnosis. ${ }^{44}$ However, the number of visits did not differ between children with and without diabetic ketoacidosis $(\mathrm{P}=0.30) .{ }^{44}$ A US study found that significantly more children who presented with diabetic ketoacidosis had one or more medical consultations in the week before diagnosis $(38.8 \%(285 / 735) v 34.4 \%(1104 / 3212), \mathrm{P}=0.026){ }^{46}$ 


\section{Delayed treatment and presence of structured diabetes team}

One multicentre study across Europe showed that a delay of more than 24 hours between diagnosis and treatment was associated with a small increased risk of children developing diabetic ketoacidosis (odds ratio 1.74 (1.10 to 2.77 )).$^{42}$ One Kuwaiti study compared the frequency of diabetic ketoacidosis in children diagnosed in hospitals with and without a structured diabetes team, and found that diabetic ketoacidosis was significantly more common in hospitals lacking a structured diabetes team $(\mathrm{P}<0.002) .{ }^{47}$

\section{Disease factors Duration of symptoms}

Four studies compared the duration of symptoms in children presenting with and without diabetic ketoacidosis. 25353861 Although the mean duration of symptoms was similar in both groups, it was slightly shorter in those with diabetic ketoacidosis (16.5 (SE 6.2) days and 17.1 (6.0) days respectively, $\mathrm{P}<0.001$ ). Two other studies found that children with diabetic ketoacidosis had a shorter duration of symptoms $(\mathrm{P}<0.005),{ }^{47}$ but the percentage of children with symptoms for less than two weeks did not differ between the groups $(24.8 \%$ (108/436) and $24.2 \%$ $(145 / 601)$ for those with and without diabetic ketoacidosis respectively, $\mathrm{P}=0.80) .{ }^{42}$ After adjustment for age, sex, family history of type 1 diabetes, and whether children were diagnosed in primary or secondary care, the duration of classic symptoms (enuresis or nocturia, polyuria, polydipsia, change in appetite, weight loss, candidiasis, and fatigue) also did not predict a diagnosis of new onset diabetes before progression to diabetic ketoacidosis. $^{44}$

\section{Pattern and frequency of symptoms}

The six studies which compared symptom pattern and frequency between children with and without diabetic ketoacidosis showed inconsistent findings. One found no difference in the frequency of any of the typical symptoms of diabetes (enuresis or nocturia, polyuria, or polydipsia), ${ }^{44}$ whereas children with diabetic ketoacidosis presented more often with vomiting, ${ }^{43} 3540$ abdominal pain, ${ }^{43}{ }^{35}$ dyspnoea, ${ }^{40}$ weakness,${ }^{35}$ anorexia, ${ }^{35}$ and changes in mental status. ${ }^{35}$ Two studies also showed that children with diabetic ketoacidosis had significantly greater weight loss than those without (4.84\% (SD 3.87\%) of body weight $v 3.32 \%$ (3.53\%), $\mathrm{P}<0.0001$; and 3.35 (SD 2.07) $\mathrm{kg} v 1.45$ (1.85) kg, $\mathrm{P}<0.005),{ }^{42} 61$ while a third study showed no difference $(\mathrm{P}=0.296){ }^{40}$

\section{Preceding infection or febrile illness}

Three studies included data on the effect of a preceding infection or febrile illness. In two, a history of infection or febrile illness was associated with an increased risk of diabetic ketoacidosis (odds ratios 6.50 (2.06 to 20.53) and 1.87 (1.05 to 3.33), not combined because $\left.\mathrm{I}^{2}=72.2 \%\right) .{ }^{330}$ In the third study febrile illness before the start of symptoms was more common in the groups with shorter duration of symptoms $(<1$ month), but it did not change the percentage with severe ketoacidosis. ${ }^{62}$

\section{Other factors}

\section{Time of year}

Two studies ${ }^{25}{ }^{26}$ looked at the effect of time of year on the frequency of diabetic ketoacidosis. Although the total number of cases was higher in winter than in summer, both found that the proportion of diabetic ketoacidosis cases remained stable (combined odds ratio 1.07 (0.89 to 1.28$), \mathrm{P}=0.49$ ).

\section{Background incidence of type 1 diabetes}

Only one multicentre study reported specifically on the influence of the background incidence of type 1 diabetes on the frequency of diabetic ketoacidosis. Using data from 11 centres across Europe, it showed a significant inverse correlation between the proportion presenting with diabetic ketoacidosis and the background incidence of type 1 diabetes for these centres $\left(r_{\mathrm{s}}=-0.715, \mathrm{P}=0.012\right)^{42}$

\section{Discussion Principal findings}

This systematic review provides a comprehensive synthesis of the factors associated with diabetic ketoacidosis in children and young adults presenting with new onset of type 1 diabetes. We found that younger children, those from ethnic minority groups, without medical insurance (in the US), and with a lower body mass index were at highest risk. Having a preceding infection and being exposed to diagnostic error or delayed treatment were also associated with an increased risk of developing diabetic ketoacidosis. In contrast, we found that children with a first degree relative with type 1 diabetes, with parents with higher levels of education, or who lived in an area with a higher background incidence of type 1 diabetes seemed less likely to present in diabetic ketoacidosis (see fig 2).

\section{Strengths and limitations}

Our rigorous and systematic search encompassed multiple databases and languages, and identified data on more than 24 000 children from 31 countries. Although this strengthens the generalisability of our findings, it also contributed to considerable heterogeneity in terms of design, setting, and predictors included. Despite using appropriate meta-analytic techniques with random effect models, we were unable to control fully for these differences. The studies also varied in quality, and only 18 formally assessed case ascertainment. Many were also retrospective and may have been subject to recording and recall bias. Most of the studies did not provide quantitative data for negative findings, but merely stated that no differences were observed, implying some degree of reporting bias. Although we cannot exclude publication bias, we expect this to be minimal because of the exploratory nature of the question.

Included studies also used a wide range of definitions of diabetic ketoacidosis, reflecting different international settings and periods of study. Only one ${ }^{47}$ used the current diagnostic criteria for diabetic ketoacidosis published by the International Society for Paediatric and Adolescent Diabetes. ${ }^{4}$ However, our inclusion criteria incorporated a measurement of $\mathrm{pH}(\mathrm{pH} \leq 7.2$ to $<7.36)$ or bicarbonate $(<15$ to $\leq 21 \mathrm{mmol} / \mathrm{L})$ and so consistently identified those with worse metabolic derangements. Although the absolute frequency of diabetic ketoacidosis may vary with different definitions, it is unlikely that this would substantially alter our overall conclusions. ${ }^{21}$ Finally, because of the format of the data, it was not possible to assess the independent contribution of each of the predictors we identified, but we include results of multivariate analyses where reported.

\section{Factors associated with increased risk of diabetic ketoacidosis}

Younger age was consistently associated with an increased risk of diabetic ketoacidosis at diagnosis. This increased risk was 
most noticeable in children less than 2 years old and was still present at 5 years, but by age 10 there was no significant difference. The reasons for this are probably multifactorial. Clinicians may have a lower index of suspicion for diabetes among younger children, and the classic symptoms of diabetes may be subtle and difficult to distinguish from other acute illnesses at this age. Decompensation due to dehydration and acidosis also develop more quickly in young children as the mechanisms of metabolic compensation are less developed. ${ }^{29} 38$ Moreover, $\beta$ cell destruction may be more aggressive in young children: serum levels of proinsulin $C$ peptide are lower in children under 2 years old at diagnosis of diabetes, and they continue to lose their endogenous insulin secretory capacity faster than older children after diagnosis. ${ }^{24}{ }^{63}$ Some of these factors may also explain why children with a lower body mass index seemed to be at greater risk.

Children from ethnic minority groups seem to have an increased risk of developing diabetic ketoacidosis, but it is difficult to draw strong conclusions as the studies compared different ethnic groups, and we do not know the independent effect of ethnicity (rather than sociodemographic differences). Possible explanations include difficulties in recognising the symptoms because of language and cultural barriers, lack of awareness of type 1 diabetes in ethnic minorities, and cultural or practical difficulties in accessing healthcare. ${ }^{64} 65$ These factors are also likely to contribute to the threefold increase in diabetic ketoacidosis seen in children without private health insurance in the US.

Several physician level factors were also associated with an increased risk of diabetic ketoacidosis. Children who were not diagnosed at their first visit to a doctor had a threefold increased risk of presenting in diabetic ketoacidosis, and delays in starting treatment were associated with a small increased risk. However, the contribution of delayed recognition itself was not consistent as some studies found delays contributed to diabetic ketoacidosis while others did not. The duration of symptoms was also similar in children with and without diabetic ketoacidosis, although this effect may be confounded by the age of children - as diabetic ketoacidosis is more common in younger children, who tend to have a shorter duration of symptoms. ${ }^{10}$

A history of prior infection was the only disease related factor associated with an increased risk of diabetic ketoacidosis. Infection is known to cause inflammation, pro-inflammatory cytokine release, and a counter regulatory response that collectively lead to insulin resistance and metabolic decompensation. ${ }^{66}$ The infection itself may also trigger more rapid autoimmune destruction of $\beta$ cells. Infections are associated with a transient increase in risk of type 1 diabetes, ${ }^{67}$ and there is increasing evidence for the role of enteroviruses in the early phase of type 1 diabetes through infection of $\beta$ cells and activation of innate immunity and inflammation. ${ }^{68} 69$ Alternatively, the presence of infection may mask the early symptoms of diabetes and make the diagnosis more difficult.

\section{Factors associated with a decreased risk of diabetic ketoacidosis}

Having a first degree relative with diabetes was associated with an up to sixfold decreased risk of diabetic ketoacidosis at diagnosis. The absence of any significant difference between children in whom a member of the family was subsequently diagnosed with diabetes and those without such a family history at the end of the follow-up period suggests that the protective effect of a first degree relative with diabetes at diagnosis was probably due to increased awareness among families with experience of diabetes rather than an increased genetic risk for type 1 diabetes predisposing to a milder onset of disease, as suggested previously. ${ }^{70}$ This interpretation is consistent with other observations that initial differences in metabolic indices observed at diagnosis between those with and without a family history of diabetes disappear by one year after diagnosis. ${ }^{71}$

It is also possible that some of this protective effect could be due to a family history of diabetes alerting clinicians to an increased possibility of type 1 diabetes. Better disease recognition because of improved awareness of diabetes is further supported by the finding that children from families with higher parental education were less likely to present in diabetic ketoacidosis, and that the risk of diabetic ketoacidosis was inversely proportional to background incidence of type 1 diabetes. These differences may also reflect variations in, for example, access to healthcare, child supervision, or schooling.

\section{Implications for practising clinicians}

This study has implications for clinicians in both primary and secondary care, as the vast majority of children who develop type 1 diabetes will have a consultation before diagnosis. Although type 1 diabetes can be diagnosed in primary care, a diagnosis of diabetic ketoacidosis requires measurement of serum $\mathrm{pH}$ or bicarbonate and so typically requires referral to secondary care. Furthermore, many children present directly to hospital emergency or paediatric departments. As with other serious illnesses in children, differentiating the occasional child with a serious illness from the large number with minor undifferentiated illness is challenging. The relatively easy access to point of care tests for hyperglycaemia, ketonaemia, and glycosuria, however, means that diagnosis does not require access to specialist diagnostic services (such as imaging for suspected malignancy) but, instead, a high index of suspicion. Our findings suggest that clinicians should be particularly alert for diabetic ketoacidosis in children under 5 years old, those from ethnic minority groups, and those from families with low education level or socioeconomic status.

We found clear evidence that at least some children with diabetic ketoacidosis experienced diagnostic or treatment delays. Children presenting with diabetic ketoacidosis had symptoms for a mean of two weeks, up to a third had at least one medical consultation in the week before diagnosis, and misdiagnosis was associated with a threefold increase in diabetic ketoacidosis. However, the influence of delays at the physician level on risk of diabetic ketoacidosis was not consistent across studies, and we did not identify reasons for the diagnostic errors. High rates of misdiagnosis have also been found in children presenting with type 1 diabetes without diabetic ketoacidosis, with up to $86 \%$ of children not diagnosed at first encounter. ${ }^{374359} 7273 \mathrm{In}$ these studies, common diagnostic errors included misinterpreting symptoms (such as polyuria misdiagnosed as urinary tract infection), exclusively focusing on one or more symptoms (such as oral candidiasis), and not performing appropriate investigations (such as blood glucose or urine tests). Clinicians should therefore be aware of these difficulties in diagnosis and be particularly alert for diabetic ketoacidosis in those children at higher risk. Improving awareness among parents and clinicians about the early symptoms of diabetes through diabetes education programmes-such as the community intervention in Italy, which reduced the prevalence of diabetic ketoacidosis at diagnosis from $78 \%$ to $12.5 \%{ }^{74}$ —could also decrease the frequency of diabetic ketoacidosis. 


\section{Implications for future research}

While it seems intuitive that an earlier diagnosis of diabetes should lead to a decreased risk of diabetic ketoacidosis, our review still leaves unanswered the major question of whether diabetic ketoacidosis is a consequence of delayed diagnosis and treatment or whether it reflects a more aggressive form of diabetes. ${ }^{10}$ Additionally, no studies addressed the reasons for delays in diagnosis or the relative contribution of individual, parental or physician factors. Further studies should explore the factors that influence help seeking behaviour among parents, and delineate the time course of clinical presentation of this disease. A better understanding of the patient pathway from symptom onset to diagnosis is needed to appropriately target interventions to decrease the frequency of diabetic ketoacidosis at diagnosis of type 1 diabetes in children and young adults.

We thank Isla Kuhn, Reader Services Librarian, University of Cambridge Medical Library, for her help developing the search strategy and Professor David Dunger for helpful advice throughout the study and for proofreading the manuscript.

Contributors: JAUS performed the literature search, selected articles for inclusion, extracted the data, performed the analysis, and wrote the first draft of the manuscript. FMW and MJT selected articles for inclusion, extracted the data, and reviewed and edited the manuscript. SJS assisted with the statistical analysis and reviewed and edited the manuscript.

Funding: JAUS is supported by an NIHR academic clinical fellowship and FW by an NIHR clinical lectureship. MJT is funded by NIHR programme grant "Development and implementation of new diagnostic processes and technologies in primary care," and SJS is employed by the MRC.

Competing interests: All authors have completed the Unified Competing Interest form at http://www.icmje.org/coi_disclosure.pdf (available on request from the corresponding author) and declare: no support from any organisation for the submitted work; no financial relationships with any organisations that might have an interest in the submitted work in the previous three years, no other relationships or activities that could appear to have influenced the submitted work.

Data sharing: No additional data available.

1 DIAMOND Project Group. Incidence and trends of childhood type 1 diabetes worldwide 1990-1999. Diabet Med 2006;23:857-66.

2 EURODIAB ACE Study Group. Variation and trends in incidence of childhood diabetes in Europe. EURODIAB ACE Study Group. Lancet 2000;355:873-6.

3 Ali K, Harnden A, Edge J. Type 1 diabetes in children. BMJ 2011;342:d294

4 Wolfsdorf J, Craig M, Daneman D, Dunger D, Edge J, Lee W, et al. ISPAD clinical practice consensus guidelines 2009. Chapter 10: diabetic ketoacidosis. Pediatr Diabetes 2009;10(suppl 12):118-33.

5 Edge JA, Ford-Adams ME, Dunger DB. Causes of death in children with insulin dependent diabetes 1990-96. Arch Dis Child 1999;81:318-23.

6 Rewers A, Brown A, Rewers M. Diabetic ketoacidosis at diagnosis predicts poorer glycemic control in the initial course of type 1 diabetes. Abstract presented at the Pediatric Society Meeting, Toronto, 2007.

7 Fernandez Castaner M, Montana E, Camps I, Biarnes J, Merino JF, Escriba JM, et al Ketoacidosis at diagnosis is predictive of lower residual beta-cell function and poor metabolic control in type 1 diabetes. Diabetes Metab 1996;22:349-55

8 Bowden SA, Duck MM, Hoffman RP. Young children ( $<5 \mathrm{yr}$ ) and adolescents ( $>12 \mathrm{yr})$ with type 1 diabetes mellitus have low rate of partial remission: diabetic ketoacidosis is an important risk factor. Pediatr Diabetes 2008;9:197-201.

9 Abdul-Rasoul M, Habib H, Al-Khouly M. "The honeymoon phase" in children with type 1 diabetes mellitus: frequency, duration, and influential factors. Pediatr Diabetes 2006; 7:101-7

10 Neu A, Ehehalt S, Willasch A, Kehrer M, Hub R, Ranke MB. Varying clinical presentations at onset of type 1 diabetes mellitus in children-epidemiological evidence for different subtypes of the disease? Pediatr Diabetes 2001;2:147-53.

11 Wolfsdorf J, Glaser N, Sperling MA. Diabetic ketoacidosis in infants, children, and adolescents: a consensus statement from the American Diabetes Association. Diabetes Care 2006;29:1150-9.

12 Dunger DB, Sperling MA, Acerini CL, Bohn DJ, Daneman D, Danne TP, et al. European Society for Paediatric Endocrinology/Lawson Wilkins Pediatric Endocrine Society consensus statement on diabetic ketoacidosis in children and adolescents. Pediatrics 2004;113:e133-40.

13 Wolfsdorf J, Craig ME, Daneman D, Dunger D, Edge J, Lee WR, et al. Diabetic ketoacidosis. Pediatr Diabetes 2007;8:28-43.
14 Public Health Resource Unit. Critical Appraisal Skills Programme. www.phru.nhs.uk/casp/ casp.htm

15 Dixon-Woods M, Sutton A, Shaw R, Miller T, Smith J, Young B, et al. Appraising qualitative research for inclusion in systematic reviews: a quantitative and qualitative comparison of three methods. $J$ Health Serv Res Policy 2007:42-7.

16 Higgins JP, Thompson SG. Quantifying heterogeneity in a meta-analysis. Stat Med 2002;21:1539-58.

17 Higgins JP, Thompson SG, Deeks JJ, Altman DG. Measuring inconsistency in meta-analyses. BMJ 2003;327:557-60.

18 Sadauskaite-Kuehne V, Samuelsson U, Jasinskiene E, Padaiga Z, Urbonaite B, Edenvall $\mathrm{H}$, et al. Severity at onset of childhood type 1 diabetes in countries with high and low incidence of the condition. Diabetes Res Clin Pract 2002;55:247-54.

19 Mayer-Davis EJ, Beyer J, Bell RA, Dabelea D, D'Agostino R, Imperatore G, et al. Diabetes in African American youth. Diabetes Care 2009;32(suppl 2):S112-22.

20 Pinkney JH, Bingley PJ, Sawtell PA, Dunger DB, Gale EAM. Presentation and progress of childhood diabetes mellitus: a prospective population-based study. Diabetologia 1994;37:70-4.

21 Hekkala A, Knip M, Veijola R. Ketoacidosis at diagnosis of type 1 diabetes in children in northern Finland-temporal changes over 20 years. Diabetes Care 2007;30:861-6.

22 Alvi NS, Davies P, Kirk JM, Shaw NJ. Diabetic ketoacidosis in Asian children. Arch Dis Child 2001;85:60-1.

23 Charemska D, Przybyszewski B, Klonowska B. Estimation of the severity of metabolic disorders in children with newly diagnosed insulin dependent diabetes mellitus (IDDM). Med Wieku Rozwoj 2003;7:261-70.

24 Komulainen J, Kulmala P, Savola K, Lounamaa R, Ilonen J, Reijonen H, et al. Clinical, autoimmune, and genetic characteristics of very young children with type 1 diabetes. Childhood Diabetes in Finland (DiMe) Study Group. Diabetes Care 1999;22:1950-5.

25 Neu A, Willasch A, Ehehalt S, Hub R, Ranke MB, Becker SA, et al. Ketoacidosis at onset of type 1 diabetes mellitus in children-frequency and clinical presentation. Pediatr Diabetes 2003;4:77-81.

26 Olak-Białon B, Deja G, Jarosz-Chobot P, Buczkowska EO. The occurrence and analysis of chosen risk factors of DKA among children with new onset of DMT1. Pediatr Endocrinol Diabetes Metab 2007:13:85-90.

27 Rosenbauer J, Icks A, Giani G. Clinical characteristics and predictors of severe ketoacidosis at onset of type 1 diabetes mellitus in children in a North Rhine-Westphalian region, Germany. J Pediatr Endocrinol Metab 2002;15:1137-45.

28 Salman H, Abanamy A, Ghassan B, Khalil M. Childhood diabetes in Saudi Arabia. Diabet Med 1991;8:176-8.

29 Salman H, Abanamy A, Ghassan B, Khalil M. Insulin-dependent diabetes mellitus in children: familial and clinical patterns in Riyadh. Ann Saudi Med 1991;11:302-6.

30 Al Khawari M, Shaltout A, Qabazard M, Abdella N, al Moemen J, al-Mazidi Z, et al. Incidence and severity of ketoacidosis in childhood-onset diabetes in Kuwait. Kuwait Diabetes Study Group. Diabetes Res Clin Pract 1997;35:123-8.

31 Sebastiani Annicchiarico L, Guglielmi A. The EURODIAB experience in Lazio. Ann Ig 1992;4:173-8.

32 Soliman A, al Salmi I, Asfour M. Mode of presentation and progress of childhood diabetes mellitus in the Sultanate of Oman. J Trop Pediatr 1997;43:128-32.

33 Bober E, Dundar B, Buyukgebiz A. Partial remission phase and metabolic control in type 1 diabetes mellitus in children and adolescents. J Pediatr Endocrinol Metab 2001;14:435-41.

34 Komulainen J, Lounamaa R, Knip M, Kaprio EA, Akerblom HK. Ketoacidosis at the diagnosis of type 1 (insulin dependent) diabetes mellitus is related to poor residual beta cell function. Arch Dis Childhood 1996;75:410-5.

35 Ting WH, Huang CY, Lo FS, Hung CM, Chan CJ, Li HJ, et al. Clinical and laboratory characteristics of type 1 diabetes in children and adolescents: experience from a medical center. Acta Paediatr Taiwan 2007;48:119-24.

36 Maniatis AK, Goehrig SH, Gao D, Rewers A, Walravens P, Klingensmith GJ. Increased incidence and severity of diabetic ketoacidosis among uninsured children with newly diagnosed type 1 diabetes mellitus. Pediatr Diabetes 2005;6:79-83

37 Mallare JT, Cordice CC, Ryan BA, Carey DE, Kreitzer PM, Frank GR. Identifying risk factors for the development of diabetic ketoacidosis in new onset type 1 diabetes mellitus. Clin Pediatr (Phila) 2003;42:591-7.

38 Samuelsson U, Stenhammar L. Clinical characteristics at onset of type 1 diabetes in children diagnosed between 1977 and 2001 in the south-east region of Sweden. Diabetes Res Clin Pract 2005;68:49-55

39 Pocecco M, Nassimbeni G. Distribution of new cases of insulin-dependent diabetes mellitus (IDDM) by age, sex, seasonality, and clinical characteristics at onset in youngsters from the Friuli Venezia Giulia region from 1987 to 1990. Pediatr Med Chir 1993;15:489-92.

40 Xin Y, Yang M, Chen XJ, Tong YJ, Zhang LH. Clinical features at the onset of childhood type 1 diabetes mellitus in Shenyang, China. J Paediatr Child Health 2010;46:171-5.

41 Schober E, Rami B, Waldhoer T. Diabetic ketoacidosis at diagnosis in Austrian children in 1989-2008: a population-based analysis. Diabetologia 2010;53:1057-61.

42 Levy-Marchal C, Patterson CC, Green A. Geographical variation of presentation at diagnosis of type I diabetes in children: the EURODIAB study. Diabetologia 2001;44(suppl 3):B75-80.

43 Blanc N, Lucidarme N, Tubiana-Rufi N. Factors associated to ketoacidosis at diagnosis of type 1 diabetes in children. Archives de Pediatrie 2003;10:320-5.

44 Quinn M, Fleischman A, Rosner B, Nigrin DJ, Wolfsdorf Jl. Characteristics at diagnosis of type 1 diabetes in children younger than 6 years. J Pediatr 2006;148:366-71.

45 Roche EF, Menon A, Gill D, Hoey H. Clinical presentation of type 1 diabetes. Pediatr Diabetes 2005;6:75-8.

46 Bui $\mathrm{H}$, To T, Stein R, Fung K, Daneman D. Is diabetic ketoacidosis at disease onset a result of missed diagnosis? J Pediatr 2010;156:472-7.

47 Abdul-Rasoul M, Al-Mahdi M, Al-Qattan H, Al-Tarkait N, Alkhouly M, Al-Safi R, et al Ketoacidosis at presentation of type 1 diabetes in children in Kuwait: frequency and clinical characteristics. Pediatr Diabetes 2010;11:351-6.

48 Smith CP, Firth D, Bennett S, Howard C, Chisholm P. Ketoacidosis occurring in newly diagnosed and established diabetic children. Acta Paediatrica 1998;87:537-41.

49 Mlynarski W, Zmyslowska A, Kubryn I, Perenc M, Bodalski J. Factors involved in ketoacidosis at the onset of type 1 diabetes in childhood. Endokrynol Diabetol Chor Przemiany Materii Wieku Rozw 2003;9:23-8.

50 Hodgson MI, Ossa JC, Velasco N, Urrejola P, Arteaga A. Clinical picture at the onset of type diabetes mellitus in children. Revista Medica De Chile 2006;134:1535-40. 


\section{What is already known on this topic}

A sizeable proportion of children and young adults with newly diagnosed type 1 diabetes present in diabetic ketoacidosis, which carries a substantial risk of life threatening complications

It is unclear why some children present in diabetic ketoacidosis whereas others do not and whether the development of diabetic ketoacidosis is a consequence of delayed diagnosis and treatment

\section{What this study adds}

This systematic review of 46 studies including more than 24000 children in 31 different countries provides the first synthesis of the factors associated with diabetic ketoacidosis at the onset of type 1 diabetes in children and young adults

Younger age, diagnostic error, ethnic minority status, lack of health insurance in the US, lower body mass index, preceding infection, and delayed treatment were all associated with an increased risk of diabetic ketoacidosis, while having a first degree relative with type 1 diabetes at the time of diagnosis, higher parental education, and higher background incidence of type 1 diabetes appear to be protective

The mean duration between onset of symptoms and development of diabetic ketoacidosis is over 14 days, and up to a third of children have at least one medical consultation during that period, suggesting a possible window of opportunity to improve recognition

51 Prisco F, Picardi A, lafusco D, Lorini R, Minicucci L, Martinucci ME, et al. Blood ketone bodies in patients with recent-onset type 1 diabetes (a multicenter study). Pediatr Diabetes 2006; 7:223-8.

52 Mylnarski W, Zmyslowska A, Kubryn I, Perenc M, Bodalski J. Factors involved in ketoacidosis at the onset of type 1 diabetes in childhood. Endokrynol Diabetol Chor Przemiany Materii Wieku Rozw 2003;9:23-8.

53 Hekkala A, Reunanen A, Koski M, Knip M, Veijola R. Age-related differences in the frequency of ketoacidosis at diagnosis of type 1 diabetes in children and adolescents. Diabetes Care 2010;33:1500-2.

54 Tahirovic H, Toromanovic A, Bacaj D, Hasanovic E. Ketoacidosis at onset of type 1 diabetes mellitus in children in Bosnia and Herzegovina: frequency and clinical presentation. J Pediatr Endocrinol Metab 2007;20:1137-40

55 Newfield RS, Cohen D, Capparelli EV, Shragg P. Rapid weight gain in children soon after diagnosis of type 1 diabetes: is there room for concern? Pediatr Diabetes 2009;10:310-5.

56 Vehik K, Hamman RF, Lezotte D, Norris JM, Klingensmith GJ, Dabelea D. Childhood growth and age at diagnosis with type 1 diabetes in Colorado young people. Diabet Med 2009;26:961-7.

57 Sundaram PCB, Day E, Kirk JMW. Delayed diagnosis in type 1 diabetes mellitus. Arch Dis Childhood 2009;94:151-2.

58 Veijola R, Reijonen H, Vähäsalo P, Sabbah E, Kulmala P, llonen J, et al. HLA-DQB1-defined genetic susceptibility, beta cell autoimmunity, and metabolic characteristics in familial and nonfamilial insulin-dependent diabetes mellitus. J Clin Invest 1996;98:2489-95

59 Pawlowicz M, Birkholz D, Niedzwiecki M, Balcerska A. Difficulties or mistakes in diagnosing type 1 diabetes mellitus in children? The consequences of delayed diagnosis. Endokrynol Diabetol Chor Przemiany Materii Wieku Rozw 2008;14:7-12.

60 Pawlowicz M, Birkholz D, Niedzwiecki M, Balcerska A. Difficulties or mistakes in diagnosing type 1 diabetes in children? Demographic factors influencing delayed diagnosis. Pediatr diabetes 2009;10:542-9.

61 Kapellen TM, Galler A, Nietzschmann U, Schille R, Kiess W. Prevalence of diabetic ketoacidosis in newly diagnosed children and adolescents with type 1 diabetes mellitus. Experience of a center for pediatric diabetology in Germany. Monatsschrift Kinderheilkunde 2001;149:679-82.

62 Savova R, Popova G, Koprivarova K, Konstantinova M, Angelova B, Atanasova M, et al. Clinical and laboratory characteristics of type I (insulin dependent) diabetes mellitus at presentation among Bulgarian children. Diabetes Res Clin Pract 1996;34:S159-63.
63 Sochett E, Daneman D, Clarson C, Ehrlich R. Factors affecting and patterns of residual insulin secretion during the first year of type 1 (insulin-dependent) diabetes mellitus in children. Diabetologia 1987;30:453-9.

64 Weech-Maldonado R, Morales LS, Spritzer K, Elliott M, Hays RD. Racial and ethnic differences in parents' assessments of pediatric care in Medicaid managed care. Health Serv Res 2001;36:575-94.

65 Brousseau DC, Hoffmann RG, Yauck J, Nattinger AB, Flores G. Disparities for Latino children in the timely receipt of medical care. Ambul Pediatr 2005;5:319-25.

66 Rayfield EJ, Ault MJ, Keusch GT, Brothers MJ, Nechemias C, Smith H. Infection and diabetes: the case for glucose control. Am J Med 1982;72:439-50.

67 Yang Z, Zhou F, Dorman J, Wang H, Zu X, Mazumdar S, et al. Association between infectious diseases and type 1 diabetes: a case-crossover study. Pediatr Diabetes 2006; 7:146-52.

68 Tanaka S, Nishida Y, Aida K, Maruyama T, Shimada A, Suzuki M, et al. Enterovirus infection, CXC chemokine ligand 10 (CXCL10), and CXCR3 circuit: a mechanism of accelerated beta-cell failure in fulminant type 1 diabetes. Diabetes 2009:58:2285-91.

69 Hober D, Sauter P. Pathogenesis of type 1 diabetes mellitus: interplay between enterovirus and host. Nat Rev Endocrinol 2010;6:279-89.

70 Komulainen J, Knip M, Sabbah E, Vahasalo P, Lounamaa R, Akerblom HK, et al. Autoimmune and clinical characteristics of type I diabetes in children with different genetic risk loads defined by HLA-DQB1 alleles. Childhood Diabetes in Finland Study Group. Clin Sci (Lond) 1998:94:263-9.

71 O'Leary LA, Dorman JS, LaPorte RE, Orchard TJ, Becker DJ, Kuller LH, et al. Familial and sporadic insulin-dependent diabetes: evidence for heterogeneous etiologies? Diabetes Res Clin Pract 1991;14:183-90.

72 Hamilton DV, Mundia SS, Lister J. Mode of presentation of juvenile diabetes. BMJ 1976;2:211-2.

73 Soliman AT, elZalabany MM, Bappal B, AISalmi I, De Silva V, Asfour M. Permanent neonatal diabetes mellitus: epidemiology, mode of presentation, pathogenesis and growth Indian J Pediatr 1999;66:363-73.

74 Vanelli M, Chiari G, Ghizzoni L, Costi G, Giacalone T, Chiarelli F. Effectiveness of a prevention program for diabetic ketoacidosis in children. An 8-year study in schools and private practices. Diabetes Care 1999;22:7-9.

\section{Accepted: 13 May 2011}

Cite this as: BMJ 2011;343:d4092 


\section{Tables}

Table 1| Characteristics of $\mathbf{4 6}$ studies included in systematic review to identify factors associated with diabetic ketoacidosis at diagnosis of type 1 diabetes in children and young adults

\begin{tabular}{|c|c|c|c|c|c|}
\hline Study & Country & Period of study & No of study centres & Design* & Recruitment method \\
\hline Abdul-Rasoul et al, $2010^{47} \dagger$ & Kuwait & $2000-6$ & Nationwide & $\mathrm{R}$ & Hospital records \\
\hline Al Khawari et al, $1997^{30}$ & Kuwait & $1992-5$ & Nationwide & $\mathrm{P}$ & $\begin{array}{l}\text { Kuwait IDDM register; Hospital records; } \\
\text { Diabetic clinic mandatory registry }\end{array}$ \\
\hline Alvi et al, $2001^{22}$ & UK & $1987-96$ & Regional & $\mathrm{R}$ & $\begin{array}{l}\text { Local paediatricians; General practitioners } \\
\text { and diabetes nurse specialists }\end{array}$ \\
\hline Blanc et al, $2003^{43} \dagger$ & France & Not given & $\begin{array}{l}1 \text { Endocrinology and diabetes } \\
\text { department }\end{array}$ & $\mathrm{P}$ & Hospital records \\
\hline Bober et al, $2001^{33}$ & Turkey & $1991-8$ & $\begin{array}{l}1 \text { Paediatric endocrinology } \\
\text { department }\end{array}$ & $\mathrm{R}$ & Hospital records \\
\hline Bowden et al, $2008^{8}$ & USA & 2004 & 1 Children's hospital & $\mathrm{R}$ & Hospital records \\
\hline Bui et al, $2010^{46} \dagger$ & Canada & 1994-2000 & Regional & $\mathrm{R}$ & $\begin{array}{l}\text { Health insurance plan; Database of health } \\
\text { and long term care; Discharge abstract } \\
\text { database }\end{array}$ \\
\hline Charemska et al, $2003^{23}$ & Poland & 1998-2002 & 1 Children's hospital & $\mathrm{R}$ & Clinic records \\
\hline Hekkala et al, $2007^{21}$ & Finland & $1982-2001$ & 1 Paediatric department & $\mathrm{R}$ & Hospital and clinic register \\
\hline Hekkala et al, $2010^{53}$ & Finland & $2002-5$ & 27 Centres & $\mathrm{R}$ & $\begin{array}{l}\text { Paediatric diabetes register; Hospital } \\
\text { records }\end{array}$ \\
\hline Hodgson et al, $2006^{50}$ & Chile & 1988-2003 & 1 Hospital & $\mathrm{R}$ & Hospital records \\
\hline Kapellen et al, $2001^{61} \dagger$ & Germany & 1995-9 & 1 Children's hospital & $\mathrm{R}$ & Hospital records \\
\hline Komulainen et al, $1996^{34} \ddagger$ & Finland & $1986-9$ & Nationwide & $\mathrm{P}$ & $\begin{array}{l}\text { Diabetes nurses; National Central Drug } \\
\text { Registry }\end{array}$ \\
\hline Komulainen et al, $1999^{24} \dagger \ddagger$ & Finland & $1986-9$ & Nationwide & $\mathrm{P}$ & $\begin{array}{l}\text { Diabetes nurses; National Central Drug } \\
\text { Registry }\end{array}$ \\
\hline Levy-Marchal et al, $2001^{42} \dagger$ & Europe & 1989-94 & 24 EURODIAB centres & $\mathrm{R}$ & Incidence surveillance cohort \\
\hline Mallare et al, $2003^{37} \dagger$ & USA & $1995-8$ & 1 Children's hospital & $\mathrm{R}$ & Hospital records \\
\hline Maniatis et al, $2005^{36}$ & USA & $2002-3$ & 1 Diabetes centre & $\mathrm{R}$ & Diabetes centre records \\
\hline Mayer-Davies et al, $2009^{19}$ & USA & $2002-5$ & 6 Clinical centres & $\mathrm{P}$ & $\begin{array}{l}\text { Reporting network of clinics and } \\
\text { healthcare providers; Hospital discharge, } \\
\text { billing, and paediatric endocrinology case } \\
\text { lists; Mailed survey to providers likely to } \\
\text { see children not included in above }\end{array}$ \\
\hline Mlynarski et al, $2003^{49}$ & Poland & $1997-2001$ & 1 Diabetes centre & $\mathrm{P}$ & Hospital records \\
\hline Neu et al, $2003^{25} \dagger$ & Germany & $1987-97$ & $\begin{array}{l}31 \text { Paediatric departments, } 1 \\
\text { diabetes centre }\end{array}$ & $\mathrm{R}$ & $\begin{array}{l}\text { Hospital records; Questionnaire to } \\
\text { members of Diabetic Patients Association }\end{array}$ \\
\hline Newfield et al, $2009^{55}$ & USA & 1998-2001 & 1 Children's hospital & $\mathrm{R}$ & Hospital database \\
\hline Olak-Bialori et al, $2007^{26}$ & Poland & $2004-5$ & $\begin{array}{l}1 \text { Children's endocrinology and } \\
\text { diabetes centre }\end{array}$ & $\mathrm{R}$ & Clinic records \\
\hline Pawlowicz et al, $2008^{59} \S$ & Poland & 1999-2004 & $\begin{array}{l}\text { 1 Paediatric endocrinology } \\
\text { department }\end{array}$ & $\mathrm{R}$ & $\begin{array}{l}\text { Hospital records; Regional diabetic } \\
\text { polyclinic records }\end{array}$ \\
\hline Pawlowicz et al, $2009^{60}+\S$ & Poland & 1999-2005 & $\begin{array}{l}1 \text { Paediatric endocrinology } \\
\text { department }\end{array}$ & $\mathrm{R}$ & $\begin{array}{l}\text { Hospital records; Regional diabetic } \\
\text { outpatient clinics }\end{array}$ \\
\hline Pinkney et al, $1994^{20}$ & UK & $19901985-6$ & Regional & $\mathrm{P}$ & $\begin{array}{l}\text { Prospective registration; Hospital } \\
\text { discharge records and death certificates; } \\
\text { General practitioners }\end{array}$ \\
\hline Pocecco et al $1993^{39}$ & Italy & $1987-90$ & $\begin{array}{l}14 \text { Paediatric departments, } 14 \\
\text { diabetes services }\end{array}$ & $\mathrm{R}$ & $\begin{array}{l}\text { Departmental records; Central register for } \\
\text { all patients receiving drug reimbursement }\end{array}$ \\
\hline Prisco et al, $2006^{51}$ & Italy & 2003 & $\begin{array}{c}7 \text { Territorial reference } \\
\text { hospitals }\end{array}$ & $P$ & Hospital records \\
\hline Quinn et al, $2006^{44} \dagger$ & USA & $1990-9$ & 1 Children's hospital & $\mathrm{R}$ & Hospital records \\
\hline Roche et al, $2005^{45}$ & Ireland & $1997-8$ & Nationwide & $P$ & $\begin{array}{l}\text { Irish paediatric surveillance unit; National } \\
\text { survey of adult physicians and } \\
\text { endocrinologists }\end{array}$ \\
\hline
\end{tabular}


Table 1 (continued)

\begin{tabular}{|c|c|c|c|c|c|}
\hline Study & Country & Period of study & No of study centres & Design* & Recruitment method \\
\hline Rosenbauer et al, $2002^{27}$ & Germany & $1993-5$ & $\begin{array}{l}41 \text { Paediatric and diabetes } \\
\text { departments }\end{array}$ & $\mathrm{R}$ & $\begin{array}{l}\text { Active clinic based surveillance system; } \\
\text { Yearly surveillance among paediatric, } \\
\text { general, and internal medicine practices }\end{array}$ \\
\hline Salman et al, $1991^{28} \S$ & Saudi Arabia & $1985-9$ & 1 Children's hospital & $\mathrm{R}$ & Hospital records \\
\hline Salman et al, $1991^{29} \S$ & Saudi Arabia & $1985-9$ & 1 Children's hospital & $\mathrm{R}$ & Hospital records \\
\hline Samuelsson et al, $2005^{38}$ & Sweden & 1977-2001 & 7 Paediatric clinics & $\mathrm{R}$ & $\begin{array}{l}\text { Medical records; Swedish Diabetes } \\
\text { Register }\end{array}$ \\
\hline $\begin{array}{l}\text { Saudaskaite-Kuehne et al, } \\
2002^{15} \dagger\end{array}$ & Sweden & $1995-9$ & 12 Hospitals & $\mathrm{P}$ & Existing case-control study \\
\hline $\begin{array}{l}\text { Saudaskaite-Kuehne et al, } \\
2002^{18} \dagger\end{array}$ & Lithuania & $1996-2000$ & Nationwide & $\mathrm{P}$ & Existing case-control study \\
\hline Savova et al, $1996^{62}$ & Bulgaria & $1974-96$ & 1 Children's hospital & $\mathrm{R}$ & $\begin{array}{l}\text { Hospital records; National centralised } \\
\text { system of insulin delivery }\end{array}$ \\
\hline †Schober et al, $2010^{41}$ & Austria & 1989-2008 & Nationwide & $\mathrm{P}$ & $\begin{array}{l}\text { Network covering all paediatric hospitals, } \\
\text { wards, and diabetologists }\end{array}$ \\
\hline Sebastiani et al, $1992^{31}$ ฯ & Italy & $1989-90$ & $\begin{array}{l}51 \text { Local health units, } 71 \\
\text { hospitals }\end{array}$ & $\mathrm{P}$ & Basic incidence surveillance cohort \\
\hline Smith et al, $1998^{48}$ & UK & $1990-6$ & 1 Children's hospital & $\mathrm{R}$ & Clinic records \\
\hline Soliman et al, $1997^{32}$ & Oman & 1990-3 & Regional (10 hospitals) & $\mathrm{P}$ & Diabetologists and pediatricians in regions \\
\hline Sundaram et al, $2009^{57} \dagger$ & UK & $2004-7$ & 1 Children's hospital & $\mathrm{R}$ & Hospital database \\
\hline Tahirovic et al, $2007^{54}$ & $\begin{array}{c}\text { Boznia and } \\
\text { Herzegovina }\end{array}$ & 1990-2005 & 1 Children's hospital & $\mathrm{R}$ & $\begin{array}{l}\text { Prospective local diabetes register; } \\
\text { Hospital records }\end{array}$ \\
\hline Ting et al, $2007^{35}$ & Taiwan & 1979-2006 & 1 Paediatric department & $\mathrm{R}$ & Hospital records \\
\hline Vehik et al, $2009^{56} \dagger$ & USA & $2002-4$ & Regional & $\mathrm{R}$ & $\begin{array}{l}\text { Search for Diabetes in Youth Study (rapid } \\
\text { reporting network of clinics and healthcare } \\
\text { providers) }\end{array}$ \\
\hline Veijola et al, $1996^{58} \ddagger$ & Finland & $1986-9$ & Nationwide & $\mathrm{P}$ & $\begin{array}{l}\text { Diabetes nurses; National Central Drug } \\
\text { Registry }\end{array}$ \\
\hline Xin et al, $2010^{40}$ & China & $2004-8$ & 1 Hospital & $\mathrm{R}$ & Hospital records \\
\hline
\end{tabular}

${ }^{*} \mathrm{R}=$ Retrospective; $P=$ Prospective.

†Papers assessed as key papers through quality assessment.

$\ddagger$ Papers probably based on the same cohort of children, but not possible to combine the results as the later study (Komulainen et al,1999 ${ }^{24}$ ) included only those children with blood $\mathrm{pH}, \mathrm{c}$ peptide, and $\mathrm{HbA}_{1 \mathrm{c}}$ measurements, whereas earlier papers (Komulainen et al, $1996^{34}$ and Veijola et al, $1996^{58}$ ) report on different data. The three papers are therefore reported as separate studies, but the children included only once in the total number of children studied.

§Probably overlap in the subjects reported in these papers as the children were recruited from the same hospitals over the same time, but, because the numbers differed in the two papers, it was not possible to combine the data.

IThis paper reports on the EURODIAB experience in Lazio. Although Lazio is also included in the combined report of the EURODIAB study (Levy-Marchal et al, $2001^{42}$ ), the numbers of subjects and focus of analysis are different and so this report is treated as a separate study. 
Table 2/ Characteristics of subjects in $\mathbf{4 6}$ studies included in systematic review to identify factors associated with diabetic ketoacidosis at diagnosis of type 1 diabetes in children and young adults

\begin{tabular}{|c|c|c|c|c|c|c|}
\hline \multirow[b]{2}{*}{ Study } & \multirow[b]{2}{*}{ Sample size } & \multirow[b]{2}{*}{ Age (years) } & \multirow[b]{2}{*}{ Male (\%) } & \multicolumn{3}{|c|}{ Diabetic ketoacidosis } \\
\hline & & & & Definition(s) & $\begin{array}{l}\text { Ascertainment } \\
\text { (\%) }\end{array}$ & Prevalence (\%) \\
\hline Abdul-Rasoul et al, $2010^{47}$ & 677 & $0-<12$ & 47.4 & $\begin{array}{c}\mathrm{pH}<7.3 \text { or } \mathrm{HCO}_{3}<15 \mathrm{mmol} / \mathrm{L} \text {, with ketonuria and } \\
\text { glucose }>11 \mathrm{mmol} / \mathrm{L}\end{array}$ & 93.9 & 37.7 \\
\hline Al Khawari et al, $1997^{30}$ & 243 & $0-<15$ & 53.1 & $\begin{array}{c}\mathrm{pH}<7.3 \text { or } \mathrm{HCO}_{3}<18 \mathrm{mmol} / \mathrm{L} \text {, with hyperglycaemia } \\
\text { and ketonuria }\end{array}$ & 92 & 49 \\
\hline Alvi et al, $2001^{22}$ & 328 & $0-15$ & 55 & $\begin{array}{c}\mathrm{pH} \leq 7.25 \text { or } \mathrm{HCO}_{3} \leq 15 \mathrm{mmol} / \mathrm{L} \text {, with } \\
\text { hyperglycaemia and ketonuria }\end{array}$ & & 27 \\
\hline Blanc et al, $2003^{43}$ & 72 & $0-<18$ & 50 & $\mathrm{pH}<7.35$ & & 54 \\
\hline Bober et al, $2001^{33}$ & 62 & $0-<18$ & 48.4 & $\mathrm{pH}<7.3$ and $\mathrm{HCO}_{3}<15 \mathrm{mmol} / \mathrm{L}$ & & 29 \\
\hline Bowden et al, $2008^{8}$ & 152 & $0-?$ & & $\mathrm{HCO}_{3}<15 \mathrm{mmol} / \mathrm{L}$, ketonuria, and hyperglycaemia & & 32.9 \\
\hline Bui et al, $2010^{46}$ & 3947 & $0-<18$ & & Diagnostic codes 250.1-250.3 & & 18.6 \\
\hline Charemska et al, $2003^{23}$ & 158 & $0-<19$ & & $\mathrm{pH} \leq 7.3$ and $\mathrm{HCO}_{3} \leq 18 \mathrm{mmol} / \mathrm{L}$ & & 38 \\
\hline Hekkala et al, $2007^{21}$ & 585 & $0-<15$ & 56.1 & $\mathrm{pH}<7.3$ or $\mathrm{HCO}_{3}<15 \mathrm{mmol} / \mathrm{L}$ & & 22.4 \\
\hline Hekkala et al, $2010^{53}$ & 1616 & $0-<15$ & 56.5 & $\mathrm{pH}<7.3$ & 97.6 & 19.4 \\
\hline Hodgson et al, $2006^{50}$ & 97 & $0-<17$ & 63 & $\mathrm{pH}<7.3, \mathrm{HCO}_{3}<15 \mathrm{mmol} / \mathrm{L}$, and ketonaemia & & 37 \\
\hline Kapellen et al, $2001^{61}$ & 104 & $0-<18$ & 55.8 & $\begin{aligned} & \mathrm{pH}<7.3, \text { glucose }>250 \mathrm{mg} / \mathrm{dL}, \text { and } \mathrm{HCO}_{3}<15 \\
& \mathrm{mmol} / \mathrm{L}\end{aligned}$ & & 29.8 \\
\hline Komulainen et al, $1996^{34}$ & 801 & $0-<15$ & 54.9 & $\mathrm{pH}<7.3$ & 100 & \\
\hline Komulainen et al, $1999^{24}$ & 745 & $0-<15$ & 55.3 & $\mathrm{pH}<7.3$ & 93 & 21.6 \\
\hline Levy-Marchal et al, $2001^{42}$ & 1037 & $0-<15$ & & $\mathrm{pH}<7.3$ & 91 & 42 \\
\hline Mallare et al, $2003^{37}$ & 139 & $0-<19$ & 52.2 & $\mathrm{pH}<7.3$ & 81.3 & 38 \\
\hline Maniatis et al, $2005^{36}$ & 359 & $0-<18$ & 57.7 & $\mathrm{pH}<7.3$ and $\mathrm{HCO}_{3}<15 \mathrm{mmol} / \mathrm{L}$ & 93.7 & 28.4 \\
\hline Mayer-Davies et al, $2009^{19}$ & 436 & $0-<20$ & & $\begin{array}{c}\mathrm{pH}<7.25 \text { (venous) or }<7.3 \text { (arterial/capillary), } \mathrm{HCO}_{3} \\
<15 \mathrm{mmol} / \mathrm{L} \text {, code } 250.1 \text { at discharge, or diabetic } \\
\text { ketoacidosis in medical notes }\end{array}$ & & 25.2 \\
\hline Mlynarski et al, $2003^{49}$ & 106 & $0-<19$ & 62.3 & $\mathrm{pH}<7.35$ & & 54.7 \\
\hline Neu et al, $2003^{25}$ & 2121 & $0-<15$ & & $\begin{array}{c}\text { Glucose }>250 \mathrm{mg} / \mathrm{dL}, \mathrm{pH}<7.3 \text {, or } \mathrm{HCO}_{3}<15 \\
\mathrm{mmol} / \mathrm{L}, \text { with ketonuria }\end{array}$ & 97.2 & 26.3 \\
\hline Newfield et al, $2009^{55}$ & 136 & $0-<18$ & 55.9 & $\mathrm{pH}<7.3$ or $\mathrm{HCO}_{3}<15 \mathrm{mmol} / \mathrm{L}$ & & 27.2 \\
\hline Olak-Bialori et al, $2007^{26}$ & 186 & $0-<18$ & 53.8 & $\begin{array}{c}\mathrm{pH}<7.3, \mathrm{HCO}_{3}<18 \mathrm{mmol} / \mathrm{L} \text {, ketonuria, and } \\
\text { glucose } 250 \mathrm{mg} / \mathrm{dL}\end{array}$ & & 33 \\
\hline Pawlowicz et al, $2008^{59}$ & 335 & $0-<17$ & 51.94 & $\mathrm{pH}<7.35$ and $\mathrm{HCO}_{3}<19 \mathrm{mmol} / \mathrm{L}$ & 91.85 & 39.7 \\
\hline Pawlowicz et al, $2009^{60}$ & 474 & $0-<17$ & 51.3 & $\mathrm{pH}<7.3$ and $\mathrm{HCO}_{3}<15 \mathrm{mmol} / \mathrm{L}$ & 99.73 & 32.9 \\
\hline \multirow[t]{2}{*}{ Pinkney et al, $1994^{20}$} & 95 & $0-<21$ & 56.5 & $\mathrm{pH} \leq 7.35$ or $\mathrm{HCO}_{3} \leq 21.0 \mathrm{mmol} / \mathrm{L}$ & 一 & 26 \\
\hline & 219 & & 59.8 & & $>95$ & 25 \\
\hline Pocecco et al $1993^{39}$ & 73 & $0-<17$ & 64.4 & $\mathrm{pH}<7.36$ & 98 & 41.1 \\
\hline Prisco et al, $2006^{51}$ & 118 & $0-<19$ & 53.4 & $\begin{array}{c}\mathrm{pH}<7.3, \text { glucose }>250 \mathrm{mg} / \mathrm{dL} \text {, and capillary ketone } \\
\text { bodies }>3 \mathrm{mmol} / \mathrm{L}\end{array}$ & 98 & 32.2 \\
\hline Quinn et al, $2006^{44}$ & 247 & $0-<6$ & 59 & $\begin{array}{c}\text { Glucose }>300 \mathrm{mg} / \mathrm{dL}, \mathrm{pH}<7.3 \text { or } \mathrm{HCO}_{3} \text { or } \mathrm{tCO}_{2} \\
<15 \mathrm{mmol} / \mathrm{L}\end{array}$ & & 43.7 \\
\hline Roche et al, $2005^{45}$ & 197 & $0-<15$ & 51.2 & $\begin{array}{c}\text { Glucose }>15 \mathrm{mmol} / \mathrm{L} \text {, urinary ketones }+2, \mathrm{pH}<7.2 \\
\mathrm{HCO}_{3}<15 \mathrm{mmol} / \mathrm{L} \text {, and clinical symptoms }\end{array}$ & 90.7 & 25 \\
\hline Rosenbauer et al, $2002^{27}$ & 262 & $0-<15$ & 53.4 & $\mathrm{pH} \leq 7.35$ & 92.5 & 53.8 \\
\hline Salman et al, $1991^{28}$ & 110 & $0-<13$ & 46.3 & $\begin{array}{c}\mathrm{HCO}_{3}<15 \mathrm{mmol} / \mathrm{L} \text {, glucose }>15 \mathrm{mmol} / \mathrm{L} \text {, ketonuria, } \\
\text { and clinical features }\end{array}$ & & 67.3 \\
\hline Salman et al, $1991^{29}$ & 41 & $0-<5$ & 53.7 & $\begin{array}{c}\mathrm{HCO}_{3}<15 \mathrm{mmol} / \mathrm{L} \text {, glucose }>15 \mathrm{mmol} / \mathrm{L} \text {, ketonuria, } \\
\text { and clinical features }\end{array}$ & & 68.2 \\
\hline Samuelsson et al, $2005^{38}$ & 1903 & $0-<16$ & 54.1 & $\mathrm{pH} \leq 7.3$ & $\begin{array}{l}100 \text { (but } 78.5 \\
\text { for } \mathrm{pH})\end{array}$ & 12.8 \\
\hline Saudaskaite-Kuehne et al, $2002^{15}$ & 401 & $0-<16$ & 51.1 & $\mathrm{pH} \leq 7.2$ plus hyperglycaemia and ketonuria & $\begin{array}{l}\text { 83.4 South east } \\
\text { Sweden, } 49.5 \\
\text { Skane region }\end{array}$ & 14.5 \\
\hline
\end{tabular}


Table 2 (continued)

\begin{tabular}{|c|c|c|c|c|c|c|}
\hline \multirow[b]{2}{*}{ Study } & \multirow[b]{2}{*}{ Sample size } & \multirow[b]{2}{*}{ Age (years) } & \multirow[b]{2}{*}{ Male (\%) } & \multicolumn{3}{|c|}{ Diabetic ketoacidosis } \\
\hline & & & & Definition(s) & $\begin{array}{l}\text { Ascertainment } \\
\text { (\%) }\end{array}$ & Prevalence (\%) \\
\hline Saudaskaite-Kuehne et al, $2002^{18}$ & 286 & $0-<16$ & 46.5 & $\mathrm{pH} \leq 7.2$ plus hyperglycaemia and ketonuria & 100 & 34.6 \\
\hline Savova et al, $1996^{62}$ & 1248 & $0-<18$ & 49.4 & $\mathrm{pH}<7.34$ or acidotic breathing & & 35.3 \\
\hline Schober et al, $2010^{41}$ & 3331 & $0-15$ & 53.9 & $\mathrm{pH}<7.3$ & $>93$ & 37.2 \\
\hline Sebastiani et al $1992^{31}$ & 117 & $0-<15$ & 44 & $\mathrm{pH}<7.3$ & & 35.65 \\
\hline Smith et al, $1998^{48}$ & 79 & $0-<16$ & 58.2 & $\mathrm{pH}<7.3$ or $\mathrm{HCO}_{3}<18 \mathrm{mmol} / \mathrm{L}$ & 90 & 27 \\
\hline Soliman et al, $1997^{32}$ & 60 & $0-<15$ & & $\mathrm{pH}<7.35$ & & 41.7 \\
\hline Sundaram et al, $2009^{57}$ & 99 & $0-<16$ & 55 & $\begin{array}{c}\mathrm{pH}<7.3 \text { or } \mathrm{HCO}_{3}<15 \mathrm{mmol} / \mathrm{L} \text { with blood glucose } \\
>11 \mathrm{mmol} / \mathrm{L} \text { and ketonaemia (with or without } \\
\text { ketonuria) }\end{array}$ & & 27.2 \\
\hline Tahirovic et al, $2007^{54}$ & 100 & $0-\leq 14$ & & $\mathrm{pH}<7.3$ and $\mathrm{HCO}_{3}<15 \mathrm{mmol} / \mathrm{L}$ & 91.7 & 48 \\
\hline Ting et al, $2007^{35}$ & 304 & $0-<18$ & 48 & $\begin{array}{c}\text { Glucose }>200 \mathrm{mg} / \mathrm{dL}, \mathrm{pH}<7.3 \text { or } \mathrm{HCO}_{3}<15 \\
\mathrm{mmol} / \mathrm{L}, \text { and ketonuria }\end{array}$ & & 65 \\
\hline Vehik et al, $2009^{56}$ & 712 & $2-<18$ & 53 & $\begin{array}{c}\mathrm{pH}<7.3, \mathrm{HCO}_{3}<18 \mathrm{mmol} / \mathrm{L} \text {, or physician } \\
\text { diagnosed episode of diabetic ketoacidosis at } \\
\text { diagnosis }\end{array}$ & $75-76$ & 27 \\
\hline Veijola et al, $1996^{58}$ & 801 & $0-<15$ & 54.9 & $\mathrm{pH}<7.3$ & 100 & 21.7 \\
\hline Xin et al, $2010^{40}$ & 203 & $0-<15$ & 43.3 & $\begin{array}{c}\mathrm{pH}<7.3 \text { or } \mathrm{HCO}_{3}<15 \mathrm{mmol} / \mathrm{L} \text {, with glucose }>14 \\
\mathrm{mmol} / \mathrm{L} \text { in presence of ketonuria }\end{array}$ & & 41.9 \\
\hline
\end{tabular}


Table 3| Identified factors associated with diabetic ketoacidosis at diagnosis of type 1 diabetes in children and young adults in systematic review of 46 studies

No of children

No of contributing studies Total No (\%) with diabetic ketoacidosis

Individual patient factors

\begin{tabular}{|c|c|c|c|}
\hline Age & 32 & 18000 & $5273(29)$ \\
\hline Sex & 21 & 16969 & $4875(29)$ \\
\hline Ethnicity & 7 & 2383 & $741(31)$ \\
\hline Family history of type 1 diabetes & 6 & 2475 & $803(32)$ \\
\hline Body mass index & 2 & 4947 & $1551(31)$ \\
\hline Parental consanguinuity & 2 & 151 & $102(68)$ \\
\hline \multicolumn{4}{|l|}{ Family factors } \\
\hline Parental education & 3 & 1694 & $459(27)$ \\
\hline Family structure & 3 & 413 & $201(49)$ \\
\hline Health insurance status & 3 & 570 & 162 28) \\
\hline Rural or urban residence & 3 & 1432 & $318(22)$ \\
\hline Family income & 3 & 4764 & $935(20)$ \\
\hline Parental employment & 2 & 687 & $157(23)$ \\
\hline Social status & 1 & 314 & $80(25)$ \\
\hline \multicolumn{4}{|l|}{ Physician factors } \\
\hline Delayed diagnosis & 4 & 1347 & $555(41)$ \\
\hline Diagnostic error & 4 & 1020 & $381(37)$ \\
\hline No of medical consultations before diagnosis & 2 & 4450 & $892(20)$ \\
\hline Delayed treatment & 1 & 1037 & $436(42)$ \\
\hline Presence of structured diabetes team & 1 & 677 & $255(38)$ \\
\hline \multicolumn{4}{|l|}{ Disease factors } \\
\hline Duration of symptoms & 7 & 6393 & $1828(29)$ \\
\hline Pattern and frequency of symptoms & 6 & 3106 & $1308(42)$ \\
\hline Preceding infection or febrile illness & 3 & 1513 & $544(36)$ \\
\hline \multicolumn{4}{|l|}{ Other } \\
\hline Time of year & 2 & 2307 & $619(27)$ \\
\hline Background incidence of type 1 diabetes & 1 & 1037 & $436(42)$ \\
\hline
\end{tabular}




\section{Figures}

\begin{tabular}{|c|c|c|c|c|}
\hline $\begin{array}{l}\text { PubMed } \\
(n=602)\end{array}$ & $\begin{array}{l}\text { Scopus } \\
(n=957)\end{array}$ & $\begin{array}{l}\text { EMBASE } \\
(n=390)\end{array}$ & $\begin{array}{l}\text { CINAHL } \\
(n=40)\end{array}$ & $\begin{array}{l}\text { Web of Science } \\
\qquad(n=243)\end{array}$ \\
\hline & 1 & 1 & $\perp$ & \\
\hline \multicolumn{5}{|c|}{ Papers after duplicates removed $(n=1441)$} \\
\hline \multicolumn{5}{|c|}{$\downarrow$} \\
\hline \multicolumn{5}{|c|}{ Papers screened $(n=1441)$} \\
\hline & & \multicolumn{3}{|c|}{ Papers excluded $(n=1333)$} \\
\hline \multicolumn{5}{|c|}{ Full text of papers assessed for eligibility $(n=108)$} \\
\hline & & \multicolumn{3}{|c|}{$\begin{array}{l}\text { Papers excluded }(n=71) \text { : } \\
\text { Frequency of diabetic ketoacidosis only }(n=23) \\
\text { Not new onset diabetes }(n=8) \\
\text { Type } 2 \text { diabetes or mixed type } 1 \text { and } 2(n=7) \\
\text { No separate data on children }(n=6) \\
\text { No reference to diabetic ketoacidosis }(n=6) \\
\text { No comparison between subjects with and } \\
\text { without diabetic ketoacidosis }(n=5) \\
\text { Duplicate data }(n=4) \\
\text { Diabetic ketoacidosis not defined }(n=4) \\
\text { Unable to obtain }(n=3) \\
\text { Selective sampling }(n=2) \\
\text { Diabetic ketoacidosis inadequately defined }(n=1) \\
\text { Case series }(n=1) \\
\text { Unable to clarify missing data }(n=1)\end{array}$} \\
\hline & & \multicolumn{3}{|c|}{$\begin{array}{l}\text { Additional papers identified through citation } \\
\text { searching included in synthesis }(n=8)\end{array}$} \\
\hline \multicolumn{5}{|c|}{ Papers included in data synthesis $(n=45)$} \\
\hline \multicolumn{5}{|c|}{$\downarrow$} \\
\hline \multicolumn{5}{|c|}{ Studies included in data synthesis $(n=46)$} \\
\hline
\end{tabular}

Fig 1 Selection of studies used in review

\begin{tabular}{|c|c|c|c|}
\hline & \multicolumn{3}{|c|}{ Risk of diabetic ketoacidosis } \\
\hline & Factors increasing risk & Factors not affecting risk & Factors reducing risk \\
\hline $\begin{array}{l}\text { More studies, } \\
\text { greater consensus } \\
\text { Fewer studies, } \\
\text { weaker consensus }\end{array}$ & $\begin{array}{c}\text { Younger age } \\
\text { Diagnostic error } \\
\text { Ethnic minority status } \\
\text { Lack of health insurance (in US) } \\
\text { Lower body mass index } \\
\text { Preceding infection } \\
\text { Delayed treatment } \\
\text { Lower socioeconomic status } \\
\text { Unemployed mother }\end{array}$ & $\begin{array}{c}\text { Sex } \\
\text { Duration of symptoms } \\
\text { Rural or urban residence } \\
\text { Family structure } \\
\text { Time of year } \\
\text { Family income } \\
\text { No of medical consultations } \\
\text { before diagnosis } \\
\text { Parental consanguinuity } \\
\text { Lack of medical insurance (in France) } \\
\text { Father's employment status }\end{array}$ & $\begin{array}{l}\text { Family history of type } 1 \text { diabetes } \\
\text { Higher parental education } \\
\text { Higher background incidence } \\
\text { of type } 1 \text { diabetes } \\
\text { Presence of structured diabetes team }\end{array}$ \\
\hline $\begin{array}{l}\text { Insufficient } \\
\text { evidence }\end{array}$ & & $\begin{array}{c}\text { Pattern and frequency of symptoms } \\
\text { Delayed diagnosis }\end{array}$ & \\
\hline
\end{tabular}

Fig 2 Influence of individual, family, physician, and disease factors on risk of diabetic ketoacidosis at diagnosis of type 1 diabetes in children and young adults 


\section{Study}

<2 vears $\mathbf{v} \geq \mathbf{2}$ years old Hekkala et al $2007^{21}$ Komulainen et al $1996^{34}$ Komulainen et al $1999^{24}$ Schober et al $2010^{41}$

\section{Subtotal}

< 4 vears $v \geq 4$ years old

Maniatis et al $2005^{36}$

$<5$ vears $v>5$ years old

Al Khawari et al $1997^{30}$

Alvi et al $2001^{22}$

Bowden et al $2008^{8}$

Charemska et al $2003^{23}$

Hekkala et al $2007^{21}$

Komulainen et al $1999^{24}$

Neu et al $2003^{25}$

Olak-Bialori et al $2007^{26}$ Pinkney et al $1994^{20}$

Rosenbauer et al $2002^{27}$ Salman et al $1991^{28}$

Salman et al $1991^{29}$

Schober et al $2010^{41}$

Sebastiani et al $1992^{31}$

Soliman et al $1997^{32}$

Xin et al $2010^{40}$

Subtotal

\section{$<6$ vears $v \geq 6$ years old}

Mallare et al $2003^{37}$

Pocecco et al $1993^{39}$

Samuelsson et al $2005^{38}$

Ting et al $2007^{35}$

Subtotal

\section{< 9 vears $\mathbf{v} \geq \mathbf{9}$ years old}

Maniatis et al $2005^{36}$

<10 vears $v \geq \mathbf{1 0}$ years old

Al Khawari et al $1997^{30}$

Bober et al $2001^{33}$

Charemska et al $2003^{23}$

Hekkala et al $2007^{21}$

Komulainen et al $1996^{34}$

Mayer-Davies et al $2009^{19}$

Neu et al $2003^{25}$

Olak-Bialori et al $2007^{26}$ Pinkney et al $1994^{20}$ Rosenbauer et al $2002^{27}$ Schober et al $2010^{41}$ Sebastiani et al $1992^{31}$ Soliman et al $1997^{32}$ Xin et al $2010^{40}$

Subtotal

<11 vears $v \geq 11$ years old Mallare et al $2003^{37}$

Samuelsson et al $2005^{38}$ Subtotal

<12 vears $v \geq 12$ years old Bowden et al $2008^{8}$ <13 vears $v$ \13 years old Maniatis et al $2005^{36}$
Odds ratio $(95 \% \mathrm{Cl})$

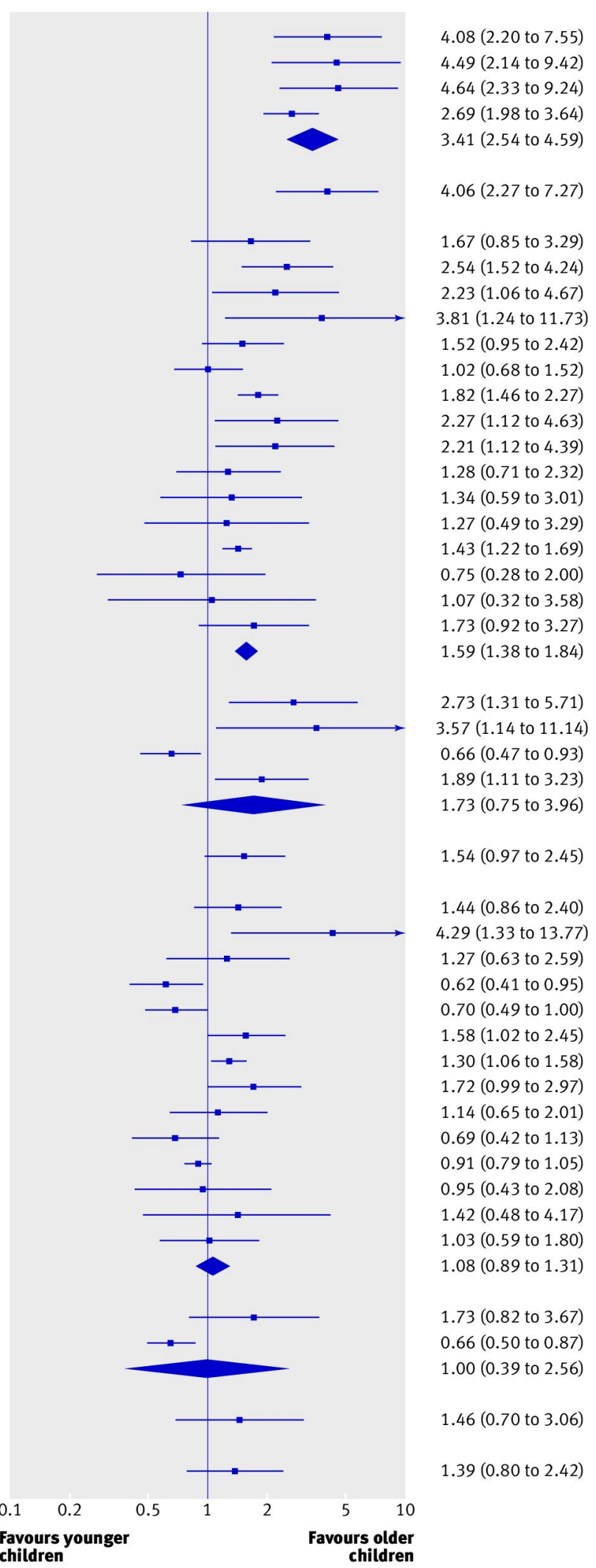

.08 (2.20 to 7.55$)$

.49 (2.14 to 9.42$)$ )

\section{Odds ratio (95\% Cl)}




\section{Study}

Hekkala et al $2007^{21}$ Hekkala et al $2010^{53}$ Hodgson et al $2006^{50}$ Maniatis et al $2005^{36}$ Mylnarski et al $2003^{49}$ Neu et al $2003^{25}$ Olak-Bialori et al $2007^{26}$ Prisco et al $2006^{51}$

Saudaskaite-Kuehne et al $2002^{15}$ Saudaskaite-Kuehne et al $2002^{18}$ Ting et al $2007^{35}$ Xin et al $2010^{40}$ Overall
Odds ratio $(95 \% \mathrm{Cl})$

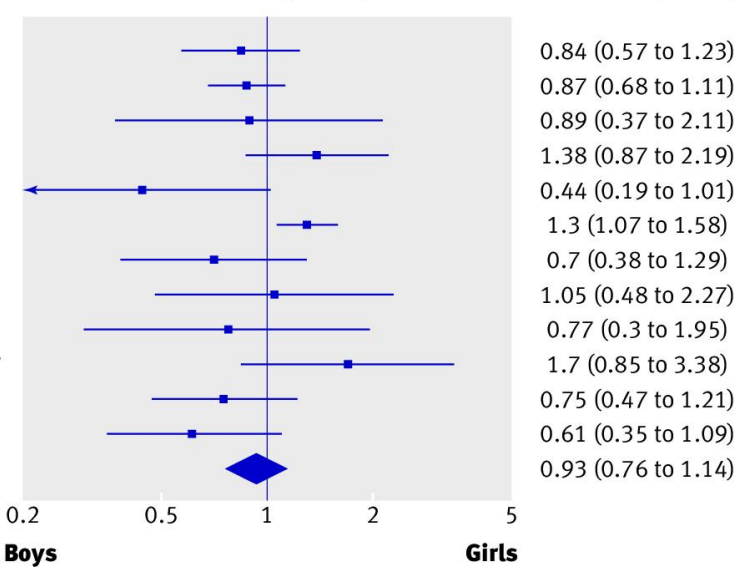

Boys Girls

Fig 4 Forest plot showing the effect of sex on the risk of presenting in diabetic ketoacidosis at diagnosis of type 1 diabetes in children and young adults

\section{Study}

Blanc et al $2003^{43}$

Mallare et al $2003^{37}$

Pawlowicz et al $2008^{59}$

Pawlowicz et al $2009^{60}$

Overall
Odds ratio $(95 \% \mathrm{Cl})$

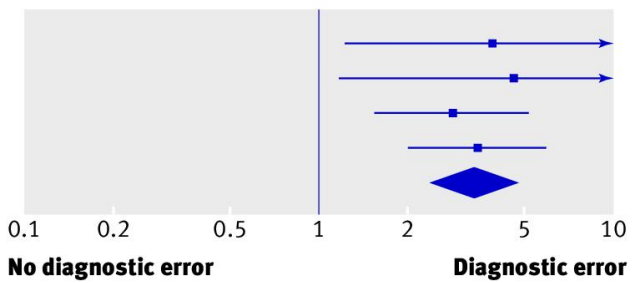

Odds ratio $(95 \% \mathrm{Cl})$

3.90 (1.24 to 12.25$)$

4.60 (1.18 to 11.65$)$

2.84 (1.56 to 5.18$)$

3.45 (2.03 to 5.87$)$

3.35 (2.35 to 4.79$)$

\section{No diagnostic error Diagnostic error}

Fig 5 Forest plot showing the effect of diagnostic error on the risk of presenting in diabetic ketoacidosis at diagnosis of type 1 diabetes in children and young adults 